\title{
Daily rhythms of body temperature around lambing in sheep measured non-invasively
}

\author{
José A. Abecia (iD), Gustavo A. María ${ }^{b}$, Laura X Estévez-Moreno ${ }^{b}$ \\ and Genaro C. Miranda-De La Lama ${ }^{\mathrm{b}}$ \\ aFacultad de Veterinaria, Instituto Universitario de Investigación en Ciencias Ambientales de Aragón

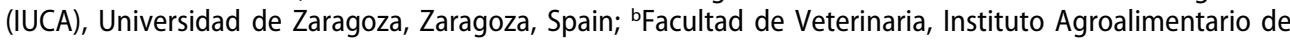 \\ Aragón (IA2), Universidad de Zaragoza-CITA, Zaragoza, Spain
}

\begin{abstract}
Fifteen ewes had data-loggers affixed under the tail, programmed to record temperature (T) every $5 \mathrm{~min}$, storing up to $72 \mathrm{~h}$ of data. Ewes were monitored to identify time of lambing (time 0 ). Lambing period lasted $5 \mathrm{~d}$; thereafter seven ewes which yielded data for 24 $\mathrm{h}$ before and after lambing were selected. Mean T ( \pm S.E.M.) was $39.03 \pm 0.02^{\circ} \mathrm{C}$. Mean $\mathrm{T}$ in the $24 \mathrm{~h}$ preceding lambing $\left(38.68 \pm 0.02^{\circ} \mathrm{C}\right)$ was lower than it was in the $24 \mathrm{~h}$ following parturition $\left(39.38 \pm 0.03^{\circ}\right.$ C) $(\mathrm{P}<0.0001)$. $T$ was lower in the $12 \mathrm{~h}$ preceding lamb birth $(38.56$ $\left.\pm 0.10^{\circ} \mathrm{C}\right)$ than it was in the previous $12 \mathrm{~h}\left(-24\right.$ to $\left.-12,38.76 \pm 0.02^{\circ} \mathrm{C}\right)$ $(\mathrm{P}<0.0001)$; thereafter, $\mathrm{T}$ was lowest precisely at parturition (mean $\mathrm{T}=38.18 \pm 0.03^{\circ} \mathrm{C}$ ) and increases rapidly and peaked (mean $\mathrm{T}=39.70$ $\left.\pm 0.04^{\circ} \mathrm{C}\right) 2 \mathrm{~h}$ after lambing. In the $12 \mathrm{~h}$ following delivery $(39.28$ $\left.\pm 0.02^{\circ} \mathrm{C}\right), \mathrm{T}$ increased, especially in the window +12 to $+24 \mathrm{~h}$ (39.51 $\pm 0.03^{\circ} \mathrm{C}$ ). In conclusion, $\mathrm{T}$ of ewes changed around parturition, with a reduction $12 \mathrm{~h}$ before lambing, followed by a rapid increase in the hours following parturition. The data-loggers used proved a high degree of sensitivity to detect physiological T changes, which confirmed that they are appropriate for use in sheep studies.
\end{abstract}

\section{ARTICLE HISTORY}

Received 20 February 2019

Accepted 6 March 2019

\section{KEYWORDS}

Sheep; temperature; lambing

\section{Introduction}

An animal's temperature $(T)$ is the result of the balance between the heat produced by basal metabolism and muscular activity of the body, and the heat lost from the body (De et al. 2017). Traditionally, rectal T has been used to measure the thermal body status of sheep; however, the common technique of inserting a lubricated thermometer into the rectum is invasive and might induce an increase in body $\mathrm{T}$ by causing stress, which increases during pregnancy (Vicente-Perez et al. 2016). In addition to the development and implementation of technical solutions, focus has increased on the use of noninvasive and continuous measurement of body core T in animals (Godyń et al. 2019). Changes in body $\mathrm{T}$ can provide valuable information about animal-environment interactions and changes in body $\mathrm{T}$ the physiological and behavioural status of animals (Pascual-Alonso et al. 2017). In that context, button data-loggers have been used to

CONTACT José A. Abecia alf@unizar.es E Facultad de Veterinaria, Instituto Universitario de Investigación en Ciencias Ambientales de Aragón (IUCA), Universidad de Zaragoza, Miguel Servet, 177, Zaragoza 50013, Spain (c) 2019 Informa UK Limited, trading as Taylor \& Francis Group 
record body $\mathrm{T}$, through surgical implantation, insertion into the gastrointestinal tract or ear canal, or attachment to the animal's skin (Roznik and Alford 2012).

Non-invasive devices have been used to record $T$ and predict parturition based on changes in $\mathrm{T}$ in cows and mares, species that have a higher economical value than sheep, and that usually require a more intensive veterinary attention. Intravaginal recording devices, based on telemetry have been used in cows (Aoki et al. 2005; Sakatani et al. 2018) and mares (Masko et al. 2018). In previous studies, we tested several methods for measuring body $\mathrm{T}$ in sheep such as subcutaneous $\mathrm{T}$ by radiofrequency, T-sensitive transponders inserted under the skin, ocular surface $T$ by infrared-thermal photography, vaginal $\mathrm{T}$ by data-loggers inserted into the vagina, and rectal T by rectal thermometer (Abecia et al. 2015; Pascual-Alonso et al. 2017). We concluded that the tail area seems to be the best location for subcutaneous transponders in sheep.

Studies have shown that body $T$ decreases a few hours before parturition in several species (sheep: Nabenishi and Yamazaki 2017; cows: Aoki et al. 2005; mares: Masko et al. 2018; dolphins: Terasawa et al. 1999); however, few studies have documented T changes after delivery (pigs: King et al. 1972; dogs: Zonturlu et al. 2008, mice: Gamo et al. 2013) and, indeed, no data are available for sheep regarding changes in $T$ in the post-partum period. The aim of this study was to measure changes in body $T$ in sheep before and after lambing, using iButton devices attached under the tail of the ewe.

\section{Material and methods}

The study was conducted at the experimental farm of the University of Zaragoza, Spain $\left(41^{\circ} \mathrm{N}\right)$. All procedures were approved by the in-house Ethic Committee for Animal Experiments from the University of Zaragoza. The care and use of animals were performed according to the Spanish Policy for Animal Protection RD1201/05, which meets the European Union Directive 2010/63 on the protection of animals used for experimental and other scientific purposes.

\subsection{Animals and data collection}

Fifteen Rasa Aragonesa ewes, which were synchronized in oestrus and artificially inseminated on 25 May, received a data-logger (DS1921K ThermochronTM iButton ${ }^{\oplus}$, Maxim Integrated, USA) under the tail, affixed by adhesive tape (Figure 1), $145 \mathrm{~d}$ after insemination. Data-loggers were programmed to record T data every $5 \mathrm{~min}$ and were capable of storing up to $72 \mathrm{~h}$ of data. Changes in T were analysed using $T$ analysis software (ExpressThermo $\left.2007^{\oplus}\right)$. At the expected time of lambing, ewes were monitored to document the actual time of lambing of each ewe (time 0 ). The lambing period of the entire group of animals lasted $5 \mathrm{~d}$; therefore, seven ewes were selected from the initial group of ewes at the end of the lambing period, which yielded a complete set of T data for at least $24 \mathrm{~h}$ before and after lambing. 


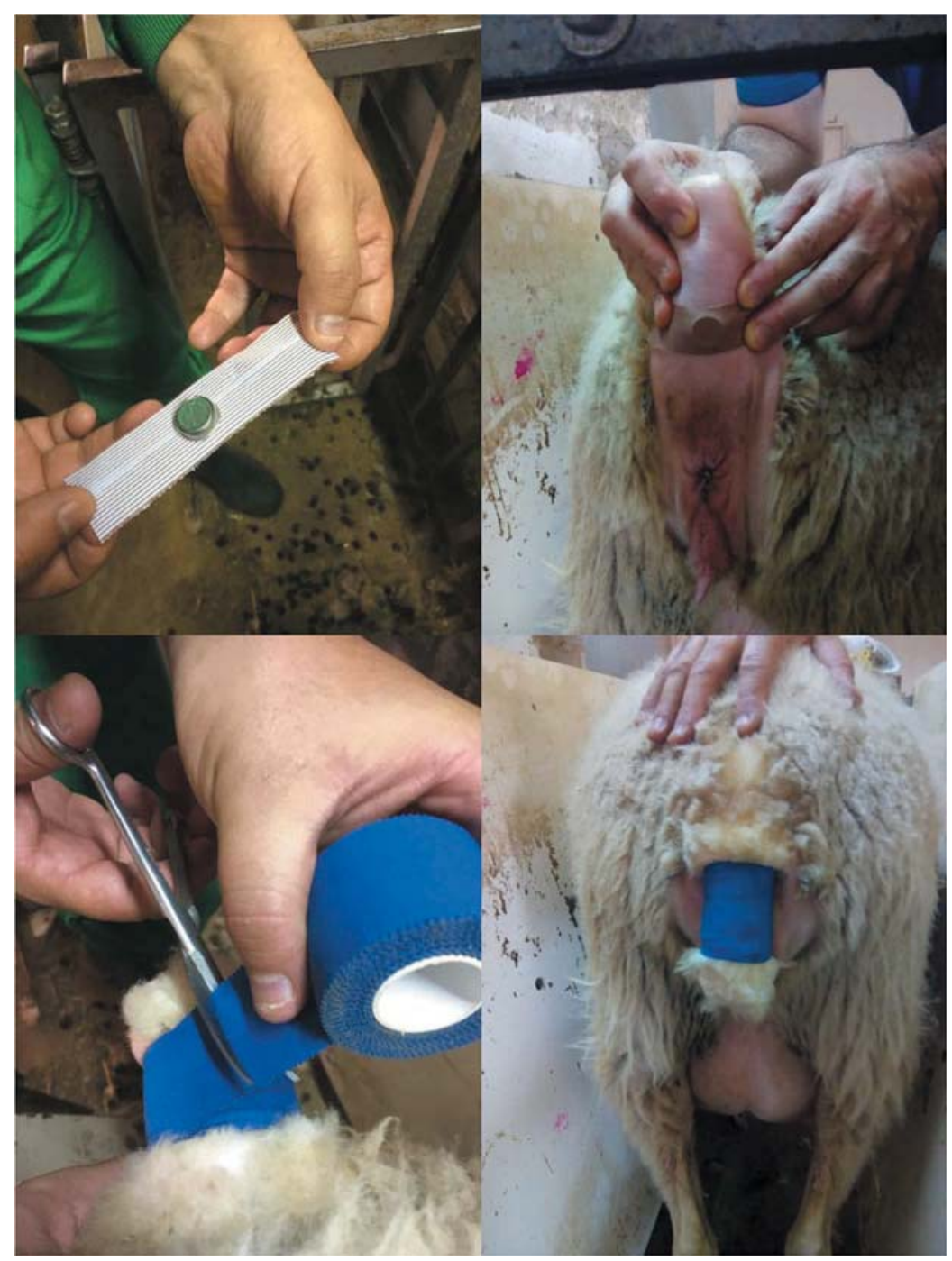

Figure 1. Data loggers used to measure and record physiological temperature in Rasa Aragonesa ewes, which were affixed to the animals with adhesive tape under the tails.

\subsection{Statistical analysis}

Time series data were analysed using a repeated measures test. Mean values $24 \mathrm{~h}$ before lambing ( $24 \mathrm{~h}$ to $0 \mathrm{~h}$ ) and $24 \mathrm{~h}$ after lambing $(+1 \mathrm{~h}$ to $+24 \mathrm{~h})$, and within 12-h windows ($24 \mathrm{~h}$ to $-12 \mathrm{~h},-11 \mathrm{~h}$ to $0 \mathrm{~h}, 1 \mathrm{~h}$ to $+12 \mathrm{~h}$, and $+13 \mathrm{~h}$ to $+24 \mathrm{~h}$ ) were calculated and evaluated statistically by paired-samples t-tests.

\section{Results}

Mean T ( \pm S.E.M.) of the ewes was $39.03 \pm 0.02^{\circ} \mathrm{C}$. Mean $\mathrm{T}$ in the $24 \mathrm{~h}$ preceding lambing $\left(38.68 \pm 0.02^{\circ} \mathrm{C}\right)$ was significantly lower than it was in the $24 \mathrm{~h}$ following parturition $(39.38 \pm$ $\left.0.03^{\circ} \mathrm{C}\right)(\mathrm{P}<0.0001)$. Mean $\mathrm{T}$ differed significantly $(\mathrm{P}<0.0001)$ among the four 12 -h periods 


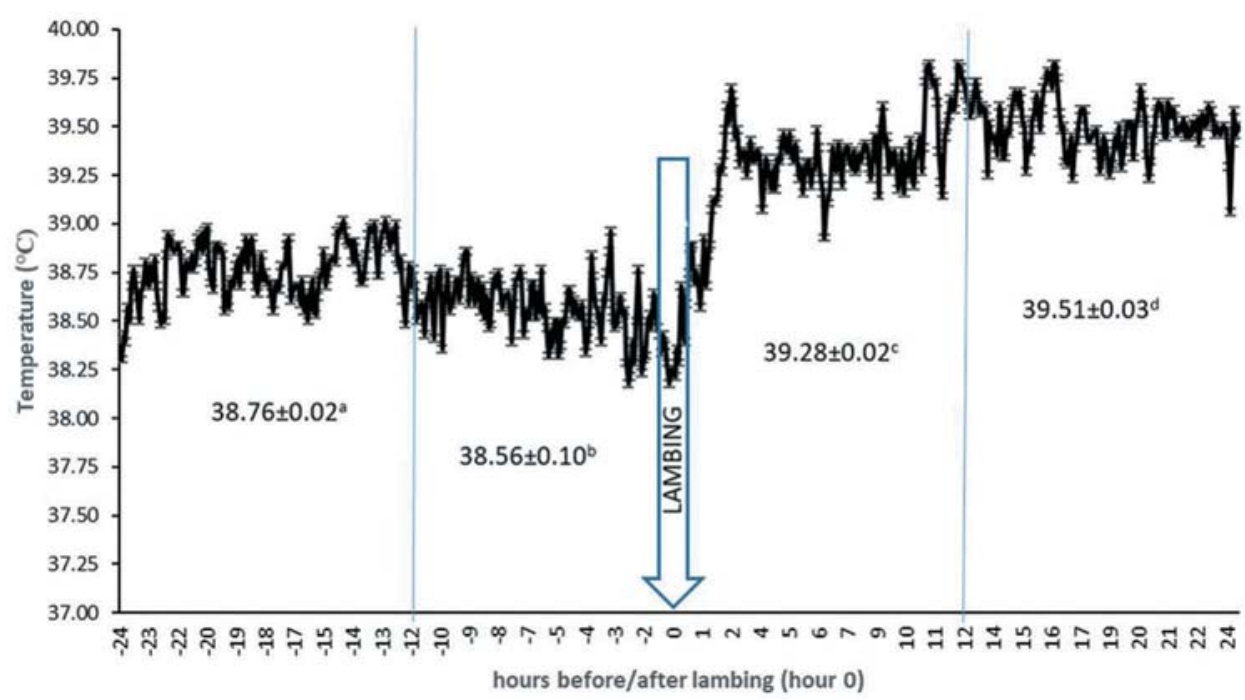

Figure 2. Mean ( \pm S.E.M.) body temperature of seven Rasa Aragonesa ewes from $24 \mathrm{~h}$ before to 24 $\mathrm{h}$ after lambing (time 0 ). Mean values of 12 -h windows were calculated. Different superscripts indicate significant differences $(P<0.0001)$.

(Figure 2); specifically, ewes experienced a significant decrease in their $\mathrm{T}$ in the 12 $\mathrm{h}$ preceding lamb birth and was lowest precisely at parturition (mean $=\mathrm{e} 38.18 \pm 0.03^{\circ} \mathrm{C}$ ); thereafter, their $\mathrm{T}$ increased and peaked (mean $\left.=39.70 \pm 0.04^{\circ} \mathrm{C}\right) 2 \mathrm{~h}$ after lambing. In the 12 $\mathrm{h}$ following delivery, $\mathrm{T}$ increased, which was most pronounced in the window +12 to $+24 \mathrm{~h}$.

\section{Discussion}

The main results of the experiment are not limited to the identification of the decrease in body $\mathrm{T}$ before lambing in sheep but include the post-lambing increase in T up to $24 \mathrm{~h}$ after lamb delivery, which has not, to our knowledge, been described in this species. Other studies have described the decrease in T before parturition, only, in the rectum (Ewbank 1969; Winfield and Makin 1975) or body surface (Nabenishi and Yamazaki 2017) of sheep, in cows (Aoki et al. 2005), and dolphins (Terasawa et al. 1999) in the rectum, and in the vagina of mares (Masko et al. 2018); however, no studies have reported $\mathrm{T}$ in the hours after parturition. In mares, vaginal $\mathrm{T} 1 \mathrm{~h}$ before and at foaling were significantly lower than it was at the same time of day in the six days prior, and T tended to decrease between $-15 \mathrm{~h}$ and $-2 \mathrm{~h}$ (Masko et al. 2018). In the dolphin study, rectal temperatures were recorded at least once per day late in the pregnancy, which indicated that $\mathrm{T}$ decreased by $0.7^{\circ} \mathrm{C}$ to $1.3^{\circ} \mathrm{C}$ between $24 \mathrm{~h}$ and $12 \mathrm{~h} 12$ $\mathrm{h}$ pre-partum, and T was significantly lower than the average from $10 \mathrm{~d}$ to $1 \mathrm{~d}$ pre-partum.

A post-partum increase in T after lambing has been reported in species other than sheep. In sows, King et al. (1972) indicated that body temperature was subnormal before farrowing and, thereafter, body temperature increased significantly, coincident with parturition. They concluded that the extremely high body $T$ of some of the clinically normal post-partum animals indicated that pyrexia, in the absence of other clinical signs, should not be taken as evidence of disease. In the same species, Littledike et al. (1979) reported an increase in body $\mathrm{T}\left(1.4^{\circ} \mathrm{C}\right)$ 
associated with parturition; specifically, the increase in body $\mathrm{T}$ of the sows began about 12 $\mathrm{h}$ before the first pig was born and peaked $1-2 \mathrm{~h}$ after delivery of the last pig. Two days postpartum, mean body temperature was about $1^{\circ} \mathrm{C}$ higher than it was in the pre-partum period, and mean body $T$ increased $0.06^{\circ} \mathrm{C}$ per day in the 12-day post-partum period. A similar pattern in T pre- and post-partum have been observed in the dog (Zonturlu et al. 2008), specifically bitches experienced a decrease in rectal T $144 \mathrm{~h}$ before whelping, at which point $\mathrm{T}$ increased. In mice (Gamo et al. 2013), body T increased abruptly after parturition.

Evidently, progesterone is involved in the maintenance of T during pregnancy (Suthar et al. 2012); therefore, it is likely that the pre-partum decreases in T observed in several mammal species is associated with the reduction in the luteal support at the end of pregnancy. Although that pre-partum decrease in T might be a result of changes in circulating progesterone, little information is available on the sudden increase in T immediately after delivery. Prolactin secretion, which is involved in the induction and maintenance of milk production, might be indirectly associated with the increase in T after lambing (see review by SvennerstenSjaunja and Olsson 2005). In mice, the heat generated from milk synthesis is equivalent to $44 \%$ of gross energy intake at $21^{\circ} \mathrm{C}$ (Johnson et al. 2001), which might be a factor that contributed to the increase in T observed in Rasa Aragonesa ewes.

An objective of our study was to confirm whether temperature-recording buttons can be used as a non-invasive method for measuring the body temperature of ewes before, during, and after birth. Other studies have indicated that sheep body $T$ measured at the perineum, the axillae, and the inner thigh are strongly correlated with rectal temperature (Mendes et al. 2013); however, those areas can be affected considerably by the ambient temperature (Miranda-de la Lama et al. 2018). We measured T under the tail because it is easier to affix the logger where there is little hair and "that location offers protection from the outside temperature. An advantage of that method is that it does not interfere with any physiological process of sheep (e.g., intrauterine sensors), and can remain clean, intact, and operational.

\section{Conclusion}

In conclusion, this study has demonstrated that the body $\mathrm{T}$ of ewes changes around parturition such that they experience a decrease $12 \mathrm{~h}$ before lambing, and a rapid increase in the hours following lamb birth. In addition, the data-loggers used in this study were shown to been highly suitable for detecting changes in physiological T in sheep.

\section{Acknowledgments}

This work was partially supported by Gobierno de Aragón (BIOFITER). G, Miranda-de la Lama is funded by ARAID programme (Gobierno de Aragón, Spain)

\section{Disclosure statement}

No potential conflict of interest was reported by the authors.

\section{ORCID}

José A. Abecia (D) http://orcid.org/0000-0003-2827-3054 


\section{References}

Abecia JA, Pascual-Alonso M, Aguayo-Ulloa LA, Maria GA 2015. Comparison of several devices to measure body temperature in sheep. ProceedingS 7th EC-PLF; Milan, Italy; September.

Aoki M, Kimura K, Suzuki O. 2005. Predicting time of parturition from changing vaginal temperature measured by data-logging apparatus in beef cows with twin fetuses. Anim Reprod Sci. 86:1-12.

De K, Kumar D, Saxena VK, Naqvi SMK. 2017. Study of circadian rhythmicity of physiological response and skin temperature of sheep during summer and winter in semi-arid tropical environment. Physiol Behav. 169:16-21.

Ewbank R. 1969. The fall in rectal temperature seen before parturition in sheep. J. Reprod Fert. 19:569-571.

Gamo Y, Troup C, Mitchell SE, Hambly C, Vaanholt LM, Speakman JR. 2013. Limits to sustained energy intake. XX. Body temperatures and physical activity of female mice during lactation. J Exp Biol. 216:3751-3761.

Godyń D, Herbut P, Angrecka S. 2019. Measurements of peripheral and deep body temperature in cattle-a review. J Therm Biol. 79:42-49.

Johnson MS, Thomson SC, Speakman JR. 2001. Limits to sustained energy intake. I. Lactation in the laboratory mouse Mus musculus. J Exp Biol. 204:1925-1935.

King GJ, Willoughby RA, Hacker RR. 1972. Fluctuations in rectal temperature of swine at parturition. Can Vet J. 13:72-74.

Littledike ET, Witzel DA, Riley JL. 1979. Body temperature changes in sows during the periparturient period. Lab Anim Sci. 29:621-624.

Masko M, Domino M, Jasinski T, Skierbiszewska K, Gajewski Z. 2018. The non-invasive system of surface temperature monitoring during perinatal period in mares. Reprod Domest Anim. 53(Suppl 2):74-215.

Mendes LCN, Matsukuma BH, Oliveira GD, Peres LC, Gerardi B, Feitosa FLF, Venturoli Perri SH, Peiró JR. 2013. Effect of shearing on the skin temperature and other clinical parameters in sheep. Pesqui Vet Bras. 33:817-825.

Miranda-de la Lama GC, Rodríguez-Palomares M, Cruz-Monterrosa RG, Rayas-Amor AA, Pinheiro RSB, Galindo FM, Villarroel M. 2018. Long-distance transport of hair lambs: effect of location in pot-belly trailers on thermo-physiology, welfare and meat quality. Trop Anim Health Prod. 50:327-336.

Nabenishi H, Yamazaki A. 2017. Decrease in body surface temperature before parturition in ewes. J Reprod Dev. 63:185-190.

Pascual-Alonso M, Miranda-De la Lama GC, Aguayo-Ulloa L, Villarroel M, Mitchell M, María GA. 2017. Thermophysiological, haematological, biochemical and behavioural stress responses of sheep transported on road. J Anim Physiol Anim Nutr. 101:541-551.

Roznik EA, Alford RA. 2012. Does waterproofing Thermochron iButton dataloggers influence temperature readings? J Therm Biol. 37:260-264.

Sakatani M, Sugano T, Higo A, Naotsuka K, Hojo T, Gessei S, Uehara H, Takenouchi N. 2018. Vaginal temperature measurement by a wireless sensor for predicting the onset of calving in Japanese Black cows. Theriogenology. 111:19-24.

Suthar VS, Burfeind O, Bonk S, Dhami AJ, Heuwieser W. 2012. Endogenous and exogenous progesterone influence body temperature in dairy cows. J Dairy Sci. 95:2381-2389.

Svennersten-Sjaunja K, Olsson K. 2005. Endocrinology of milk production. Domest Anim Endocrinol. 29:241-258.

Terasawa F, Yokoyama Y, Kitamura M. 1999. Rectal temperature before and after parturition in bottlenose dolphins. Zoo Biol. 18:153-156.

Vicente-Perez R, Avendano-Reyes L, Mejia-Vazquez A, Álvarez-Valenzuela FD, Correa-Calderon A, Mellado M, Meza-Herrera CA, Guerra-Liera JE, Robinson PH, Macias-Cruz U. 2016. Prediction of rectal temperature using non-invasive physiologic variable measurements in hair pregnant ewes subjected to natural conditions of heat stress. J Therm Biol. 55:1-6.

Winfield CG, Makin AW. 1975. Prediction of the onset of parturition in sheep from observations of rectal temperature changes. Livest Prod Sci. 2:393-399.

Zonturlu AK, Aksoy OA, Kacar C. 2008. Gestation duration and rectal temperature changes during peripartum period in dogs. J Appl Anim Res. 33:199-200. 